\title{
Spatial choreography of the coronavirus
}

\author{
Irina E. Kalabikhina ${ }^{1}$, Alexander N. Panin ${ }^{1}$ \\ 1 Lomonosov Moscow State University, Moscow, 199911, Russia
}

Received 25 April 2020 • Accepted 15 May 2020 • Published 1 June 2020

Citation: Kalabikhina IE, Panin AN (2020) Spatial choreography of the coronavirus. Population and Economics 4(2): 123-152. https://doi.org/10.3897/popecon.4.e54487

\begin{abstract}
This paper offers spatial analysis of the coronavirus spread, testing and implementation of restrictive measures in the framework of social distancing within countries and Russian regions. The geography of the spread of the disease in the municipalities of the Central Federal District is presented, the speed and direction of the shift of the «center» of disease concentration are estimated. The paper uses geographical data, operational statistics on morbidity, deaths from COVID-19 and tests, official documents on restrictive measures within the framework of social distancing (on 10 April 2020). The mapping is performed on the ArcGIS geo-information platform. Some interpretations of spatial differentiation of traceable indicators are proposed.
\end{abstract}

\section{Keywords}

coronavirus, COVID-19, restrictive measures, spatial differentiation, ArcGIS, world, Russia, Moscow, municipalities, Central Federal District, centographical method

JEL codes: R10, R38, I10, Y1

\section{Introduction}

The spatial differentiation of coronavirus in the world and in a particular country, i.e. its focal nature, appears to be one of the most important features of the pandemic. Of particular interest is the spatial differentiation of the response to the pandemic by health care systems, authorities and population. Researchers have yet to link the socio-economic, geographical, political, institutional characteristics of regions and municipalities with the excess mortality during the pandemic on a specific territory. Our task now - to present a spatial differentiation between the coronavirus spread and the response to the pandemic by authorities according to official sources - seems relatively simple. However, it is necessary to interpret the results very carefully. The map is not merely a visual image, but a 
political act. Any map compiled from open statistics about COVID-19 takes on resonance and forms a new social context; the image of space created by the map can determine people's behaviour. In the case of coronavirus, both "fear pandemic", and the lack of sense of objective danger can affect the growth of the number of cases and the health system as a whole. In this sense, mapping acute social problems requires caution and sensitivity both at the stage of map creation and at the stage of interpretation, so as not to become a means of manipulating public opinion in the future. Aware of our responsibility, we try to build maps based on official data using classic techniques of cartographic science (balanced proportions, colour, symbols), and in interpretations to take into account the specifics of data collection and objective circumstances that we can see now. We emphasize in the introduction that all the data on the morbidity and mortality from COVID-19 depend on the methods of diagnosis of the disease, the number and methods of test dissemination, the level of accuracy of the tests, proportion of asymptomatic patients, methods of diagnosis of causes of death, territorial level of data analysis, period of information gathering. Therefore, all comparisons should be made with regard to the characteristics of the data, perceiving information as a reason for reflection.

\section{Methodology and data}

The proposed materials represent the first part of the results of the geo-information monitoring of the pandemic, which is conducted by the Geodemography and Spatial Development Centre of the Population Department of the Economics Faculty together with the Complex Mapping Research Laboratory of Lomonosov Moscow State University based on daily data gathered from diversified sources using the ArcGIS geo-information platform (operational and periodic demographic and socio-economic statistics, population censuses, operational statistics on morbidity and mortality from the coronavirus and testing (Johns Hopkins University 2020; WHO 2020; Rospotrebnadzor 2020), health care system statistics, geographical data, the Yandex self-isolation index for Russia and CIS countries, official information on restrictive measures imposed in different countries, Russian regions, etc.).

In this paper we present several maps on spatial differentiation of the coronavirus at the global level - the number of reported cases, the number of reported cases per 100 thousand people, mortality rate from reported cases, number of tests performed, climatic features of the coronavirus spread, the degree of rigidity of restrictive measures and the geography of protests against the imposed restrictions, and also at the Russian level - the number of infected with coronavirus per 100 thousand people at the regional and municipal level on the example of the Central Federal District and the degree of rigidity of restrictive measures in the regions. Using the centographical method (Mendeleev 1907; Polian and Treivish 1990; Panin and Tikunov 2016), we assess the direction and speed of the virus at the municipal level on the example of the Central Federal District.

In analyzing the degree of rigidity of restrictive measures against the spread of the coronavirus, we used different methods for the world and Russia. To analyze restrictive measures in different countries, we relied on the OxCGRT database (The Oxford COVID-19... 2020). The resource contains information gathered on 17 measures of government response covering: policies of mobility and contact restriction and closure of institutions (e.g., school closures and restrictions on population movements); economic and health policies (such 
as testing regimes). Besides, we also relied on our own media monitoring (the main newspapers of different countries - Le Monde, Zeitungen, The New York Times, etc.). The data obtained on the policy of containment we grouped into three blocks based on the level of rigidity of measures: rigorous level - prohibition of leaving the place of residence, closure of public venues and institutions, suspension of transport communication; average level non-regulatory movement restriction, closure of public venues and institutions, reduction of transport links; moderate level - non-regulatory compliance with prevention measures, work of public venues and institutions, reduction of transport links.

To analyze the degree of rigidity of restrictive measures in Russian regions, we have formed a database describing specific restrictive measures taken in each region, based on the collection of information in the period of pandemic on regional legal documents of various types (decrees, agreements, orders, etc. (Garant 2020)) (for example, we recorded over 1000 regional regulations in April alone). Next, we summed up the number of restrictive measures in each subject by expert assessment of the weights of all measures. For example, the closure of entry to the Chechen Republic was assessed at 3 points, document control at entry, presence of registration or verification of QR codes in the city of Moscow and the Moscow Oblast - at 2 points, control of entrants from other regions - 1 point, lack of measures to control arrivals - 0 points. The obtained points formed the basis of the restrictive measure level map, which is built throughout the region's palette of official prohibitive measures. If the number of points did not exceed 10, such a level of limitations was considered as moderate. In the range of 10 to 20 points, we recorded an average level, over 20 points - a rigorous one.

\section{Spatial differentiation of the pandemic in the world}

The current situation (late April 2020) with the new coronavirus across the world is extremely uneven. Somewhere, it has already reached its peak and began to decline (for example, China), somewhere the peak of its development is underway (USA, European countries), and a number of countries may still have to face a full-scale pandemic (developing countries). We shall note some peculiarities of the spread of the virus at the end of April.

Figure 1 shows that the largest number of infected with coronavirus is between 32.5 and 52.5 degrees north latitude (Cembalest 2020). The virus appeared and spread across the middle and northern bands of the Northern Hemisphere subtropical belt with mild wet winters in Wuhan City and the Hubei Province with a subtropical monsoon climate, where up to $90 \%$ of all those infected in China are concentrated. In South Korea, the virus spread in the subtropical monsoon-type climate belt during the winter. Across the subtropical belt in the Middle East, the virus came to Iran and then hit Italy and Spain. The subtropical belt of the Northern Hemisphere during the winter proved particularly susceptible to the spread of the coronavirus. Not only is the northern band of subtropics suffering, but the central and southern areas of this belt - Turkey, North Africa and Israel as well.

Perhaps the nature of climate creates a favourable basis for the virus spread, primarily countries in the following climatic and geographical zones suffer: the subtropics of the Northern Hemisphere, the Atlantic climate of the North Atlantic in the winter-spring period, "heat spots" of the largest cities, areas of winter recreation, areas of tourism, seaside territories (Zyryanov 2020). 


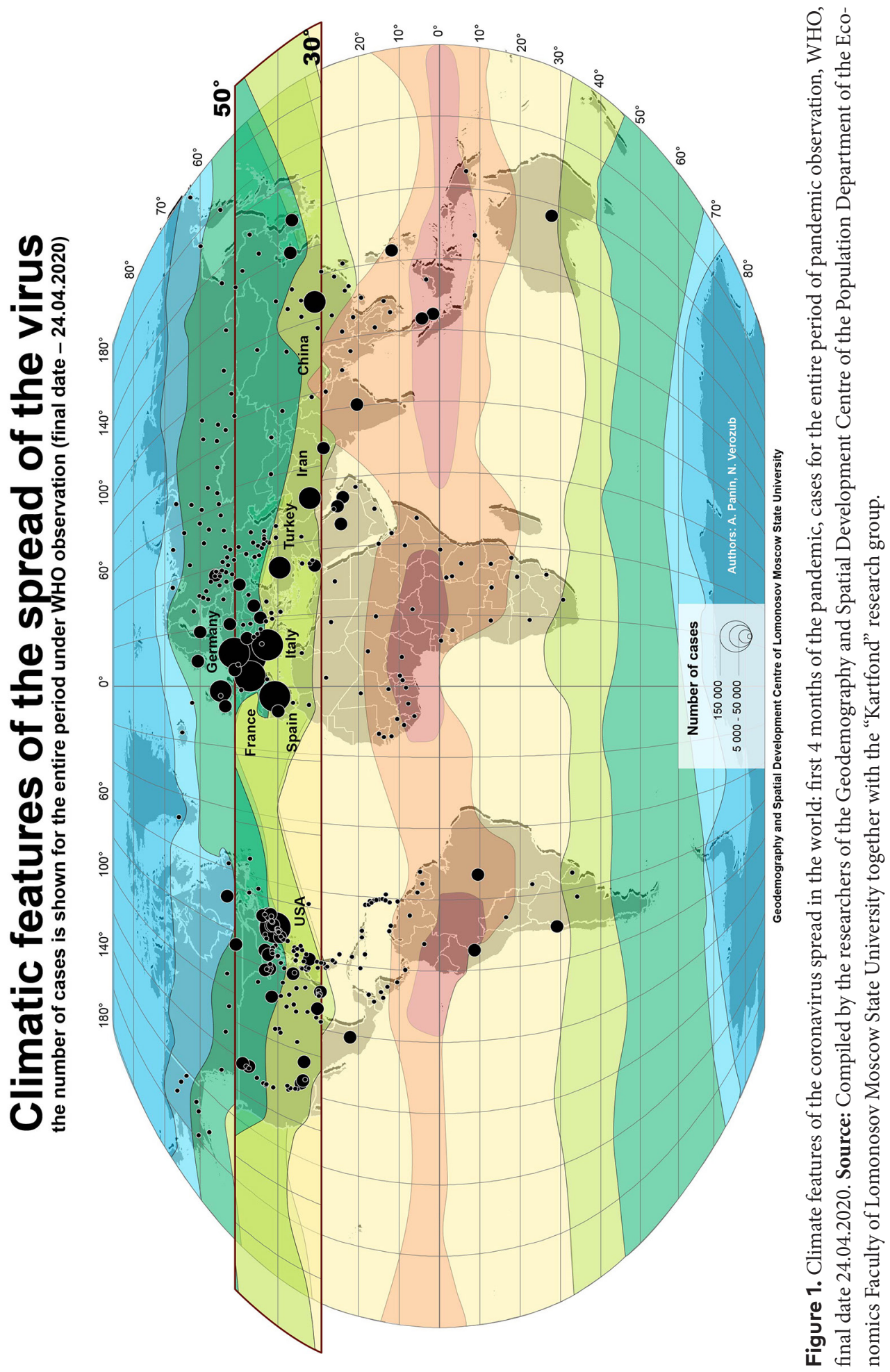


We believe that both the spread of the virus and the level of excess mortality during the pandemic will depend on a set of factors (levels of economy development and education, inclusion in world trade, the nature of state institutions, the reaction of citizens themselves, and lots more). Transport infrastructure is one of important factors. International hubs, the presence of most modes of transport in them, significant volumes of passenger traffic generally correspond to the functions and morphology of major economic centers. Virtually everywhere where we monitor at the municipal level, the focal point is formed in large agglomerations and then rapidly spreads to lower peripheral territories with a lower level of infrastructure development and standard of living.

Although it must be recognized that climate can play an explanatory role, since agglomerations and centers of economic growth owe their genesis, among other causes, to favourable climatic conditions. The development of tourism and the emergence of tourist flows is related to climatic and other favourable natural characteristics of the territories. Many relevant infrastructure projects (such as the Chinese Great Silk Road project) rely on historical trade experience and modern transport arteries of the territories. By the way, on most Chinese maps dedicated to the Silk Road, the final point is fixed in Venice and Northern Italy whose municipalities are significantly affected by the pandemic.

In terms of the absolute number of identified cases of infection, countries with a large population, mainly from the specified belt - the United States, the countries of central and southern Europe, the United Kingdom, China, Turkey, Iran, futher - Russia, Brazil, Canada, India (Fig. 2).

According to the relative number of detected cases of infection (per 1000 people), the BRIC countries (Brazil, Russia, China, India) cease to be among the first countries in terms of infection, at least on the first stage of the spread of the disease (Fig. 3).

This phenomenon may be related to the number of tests conducted in the countries, to the number of repeated tests per person, taking into account asymptomatic cases in infection statistics. The test distribution map does not match the relative incidence rate (Fig. 4). Thus, according to the number of tests Russia ranks one of the leading positions in the world -76 tests per 1 identified patient. However, it is necessary to take into account, that according to official data, in Russia testing is carried out three times per one observed. We do not have information on the number of tests in test series per observed in all other countries. Therefore, the level of testing (per 1000 residents) should be interpreted with this remark in mind.

In addition to the actual intensity of mortality among the infected, the lethality of coronavirus also depends on the number of tests performed and on how to encode the causes of death. In Figure 5, we see relatively high lethality in developing countries and developed countries with the highest incidence.

Mortality from COVID-19 in addition to the actual intensity of mortality also depends on the methods of coding the causes of death, the presence of posthumous testing. We believe that increased mortality rate was observed in countries that decided to register COVID-19 mortality as much as possible, both in cases where a person died of this disease and in cases where the disease was concomitant - USA, UK, France, Italy, Spain and even Sweden, unlike, for example, Germany, where differences in establishing the cause of death "from" and "with" COVID-19 have been implemented (Fig. 6).

The geography of public protests against the introduction of restrictive measures by governments within the framework of social distancing (Fig. 7) was completely out of line with the level of rigidity of the measures introduced (Fig. 8). The case of Brazil, where protests, weak levels of restrictive measures and a high rate of contagion were simultaneously observed, seems rather interesting in this regard. 


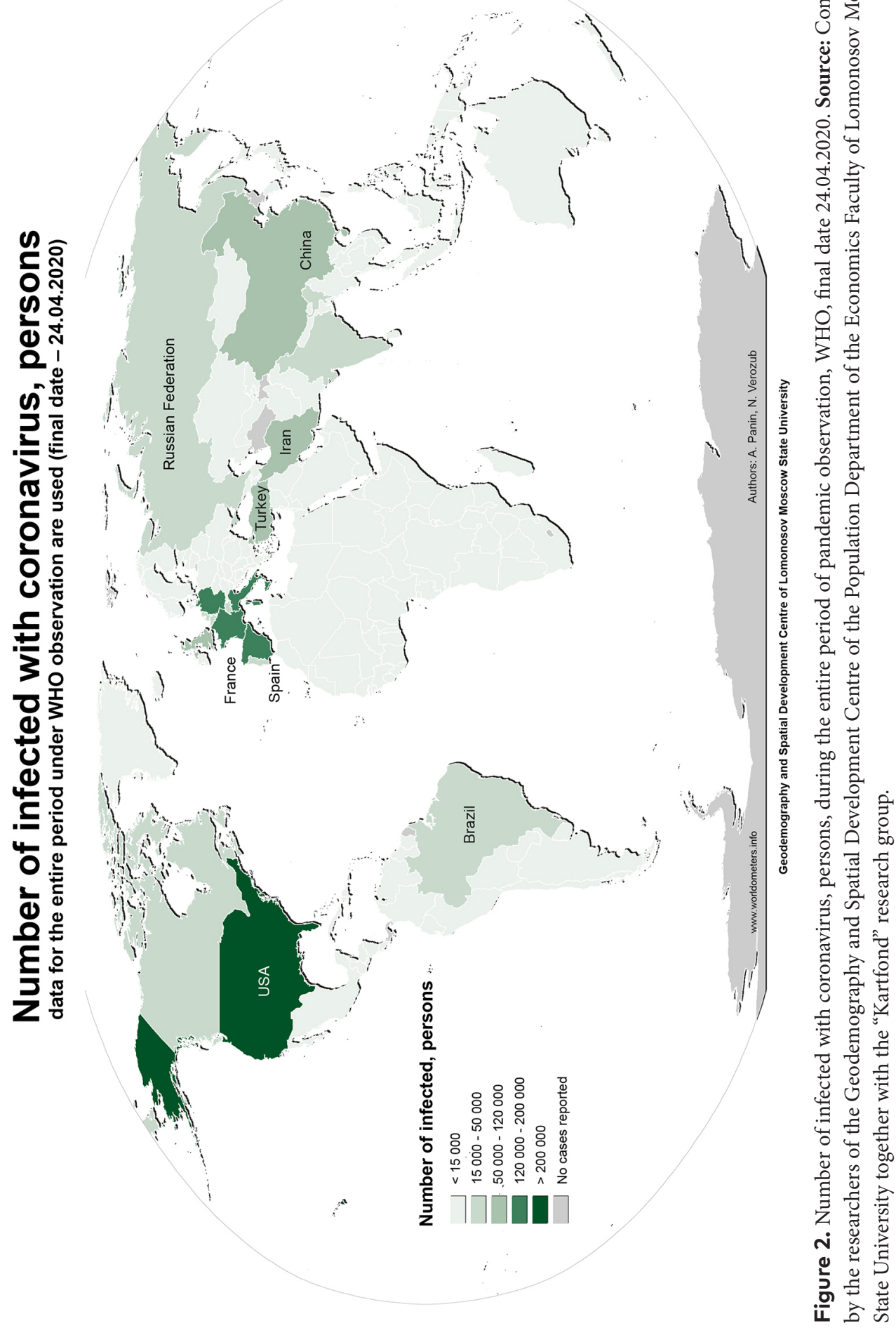









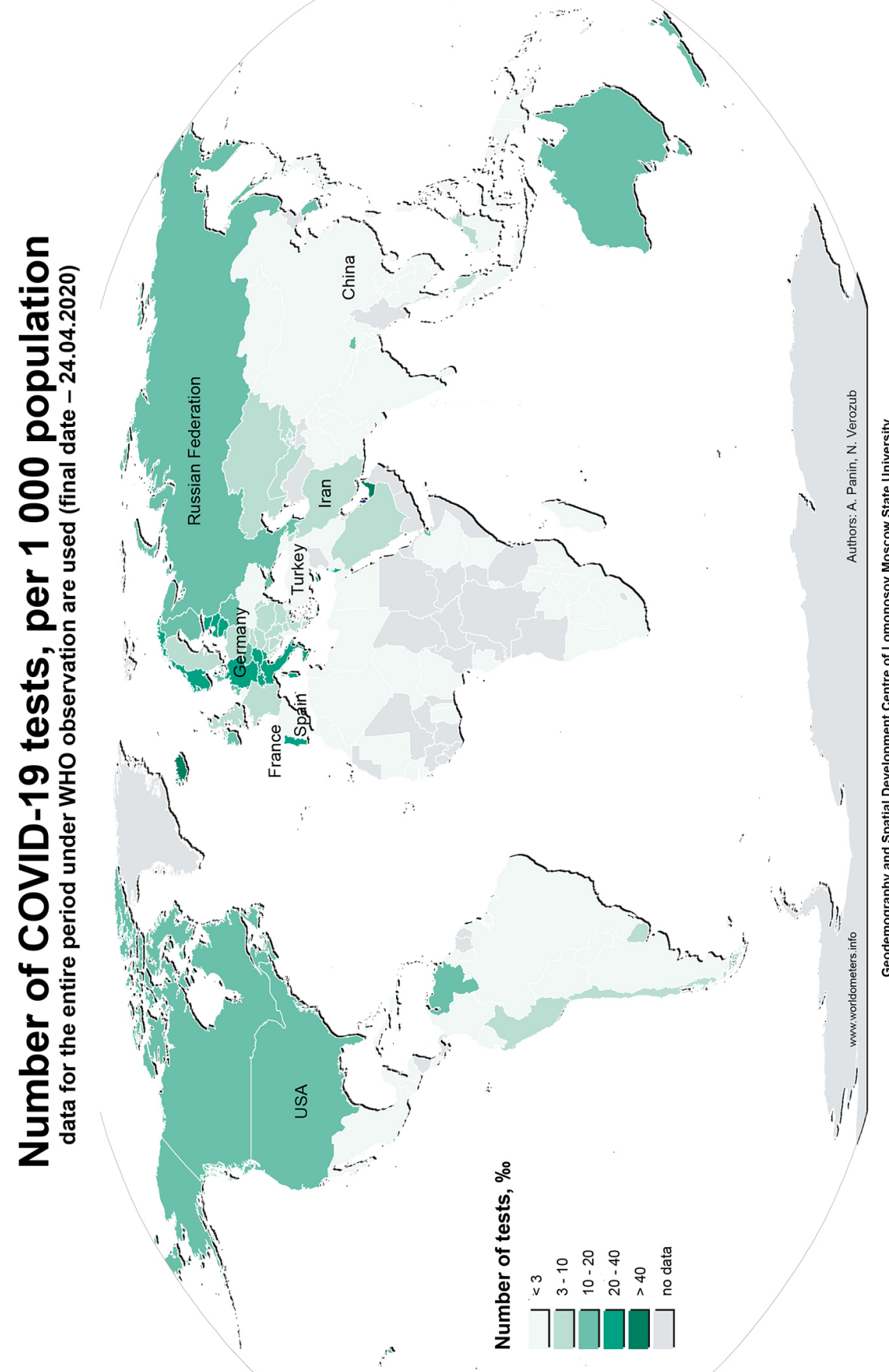




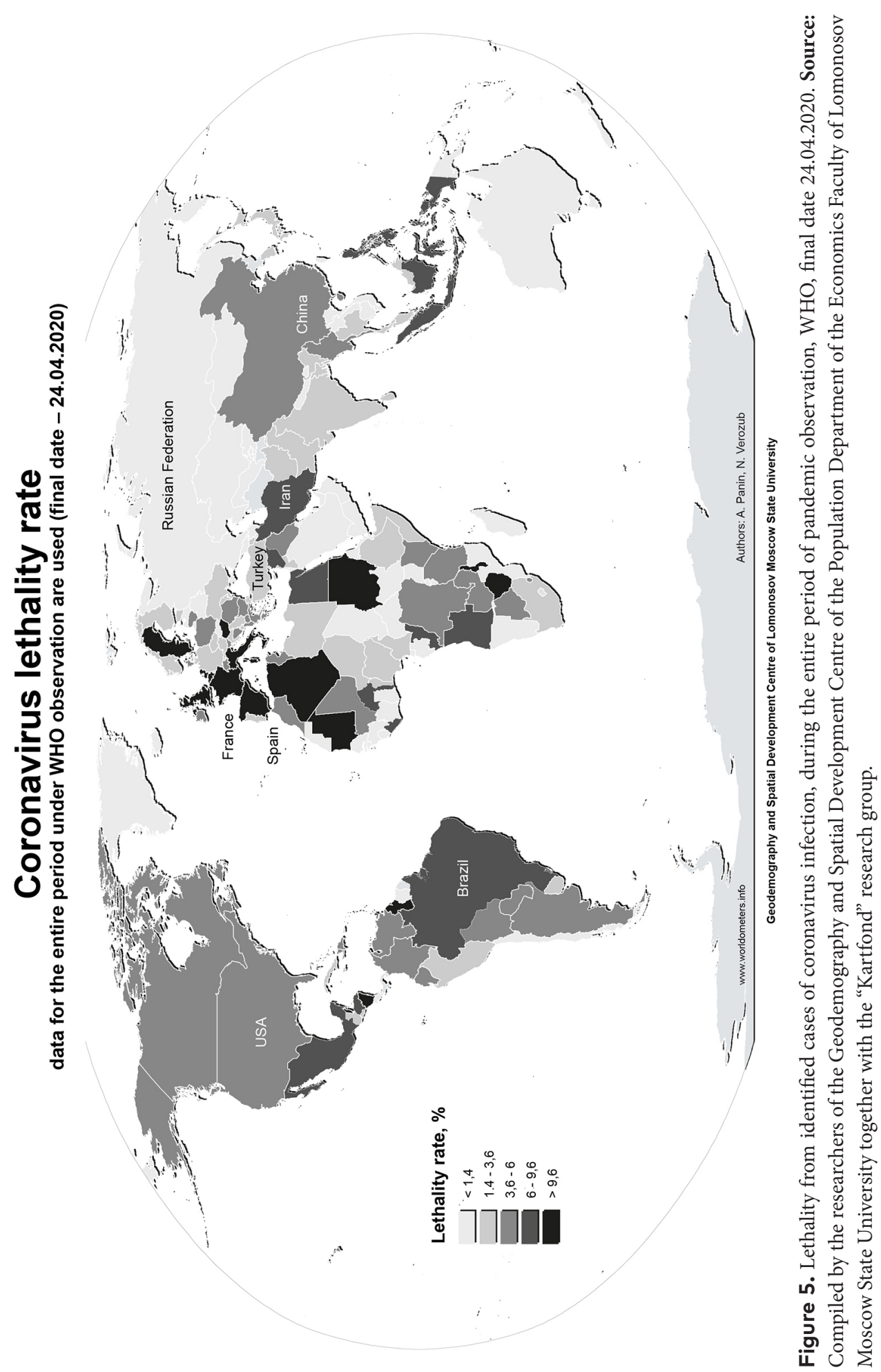




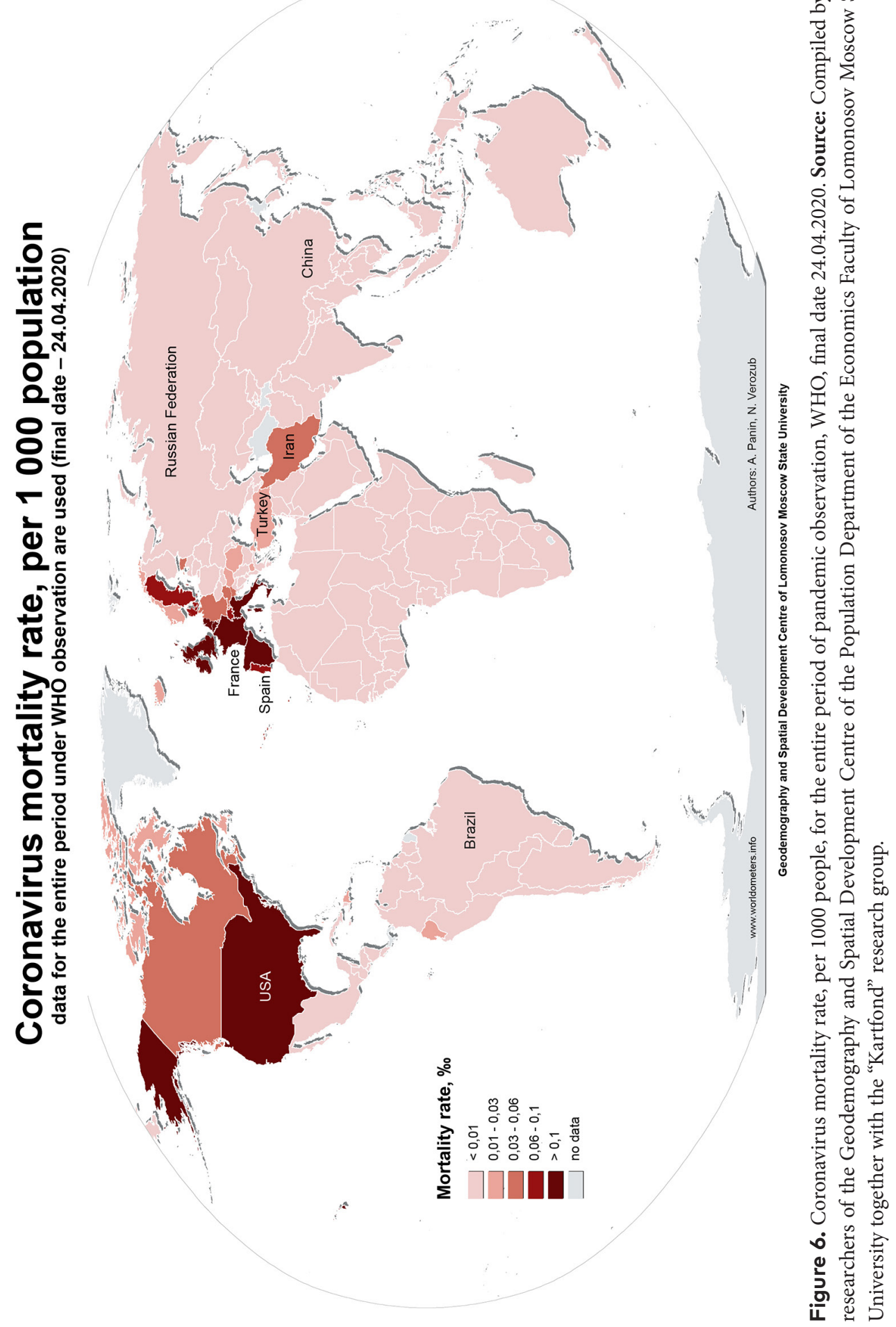




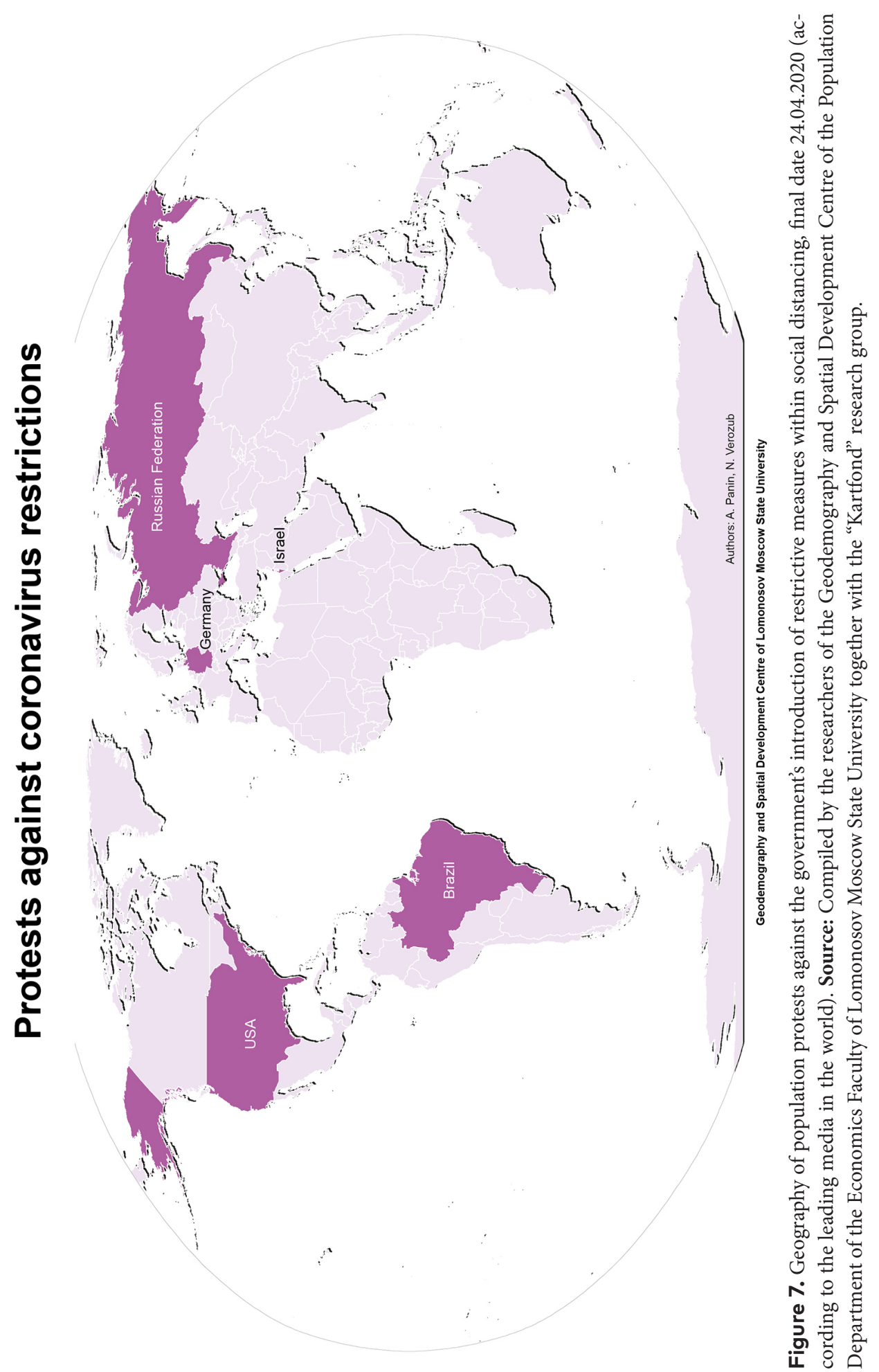




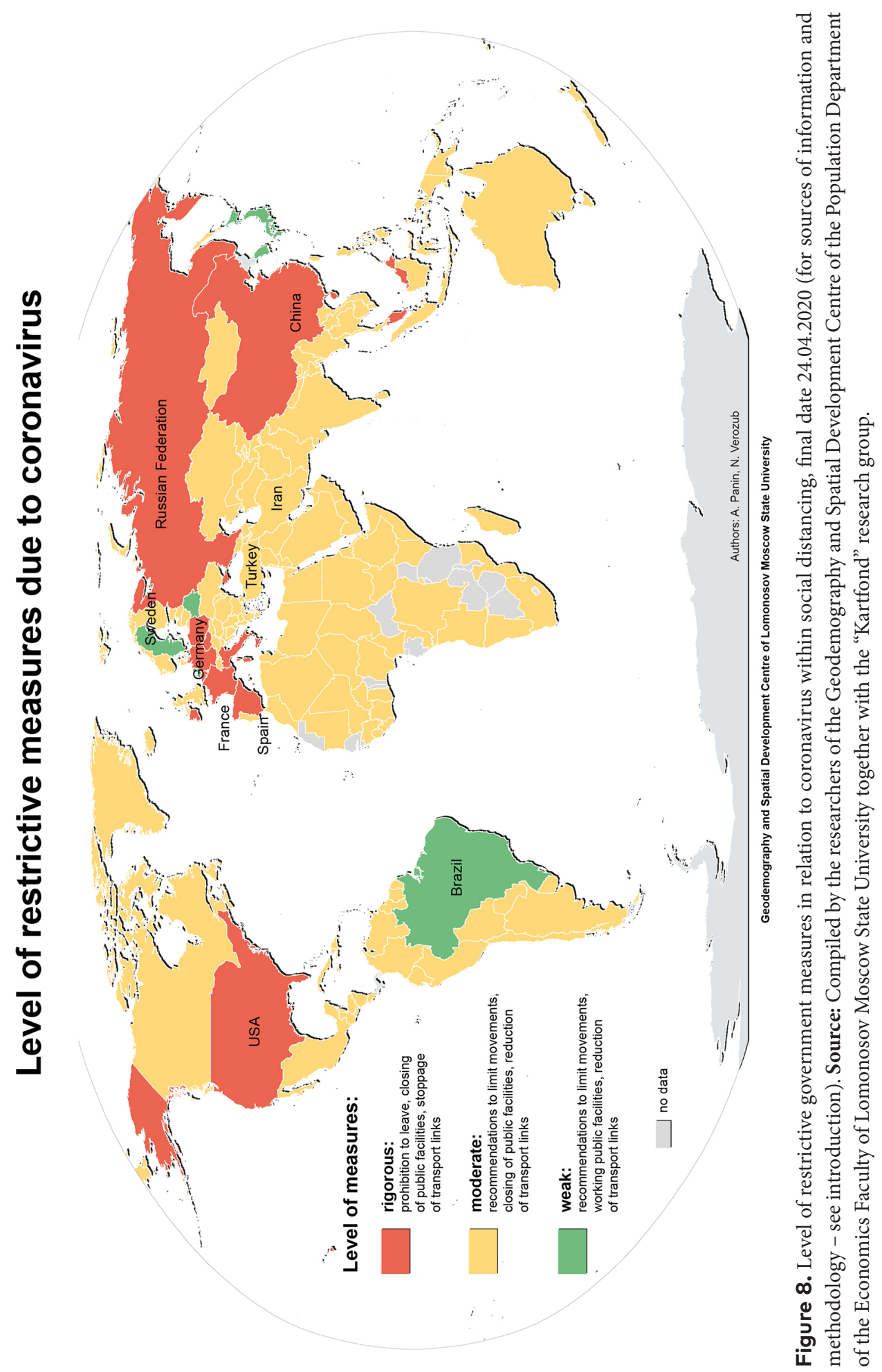




\section{Spatial differentiation of the pandemic in Russia}

Russian scene of events of coronavirus spread so far looks less dramatic than Italian or American one, and has its own set of characteristics. In the regional context, the "coronavirus dance" has already formed both ranges and trajectories of contagion. At the macro level, the situation is simultaneously affected by logistical factors, the willingness of the federal and regional authorities to form an adequate agenda for the fight against the virus, the state of health care systems of the regions, level of economic development of the territories, level of people's trust to the authorities.

As of May 1, the number of identified cases in Russia exceeded 120 thousand people. The peak is clearly not passed, and its accurate prediction is extremely difficult. Most likely, after the May holidays, we shall see an increase in the number of diseased and an expansion of regions with high incidence rates. There is fatigue of the country's inhabitants, which is directly expressed in large-scale violations of the self-isolation regime (Yandex 2020). For example, Muscovites left en masse for the May holidays, on April 30 the evening load of Moscow roads was estimated at 7 points (Yandex.Maps 2020).

The compiled maps for the number of diseased per 100 thousand people show a rapid rate of the coronavirus spread in Russia (Figs 9-11). Along with an increase in the number of affected regions, the scale of the problem has also grown. From April 1 to April 30, the number of infected people increased by 40 times (from 2.7 to 120 thousand people).

On the maps, the dynamics of the emergence of leading regions, which form four large areas with a high incidence rate, over 100 people per 100 thousand population, are clearly visible - Moscow and neighbouring regions (Kaluga, Lipetsk, Smolensk and other Oblasts), northern oil and gas and port regions (including Murmansk Oblast), North Caucasus regions (North Ossetia-Alania, Ingushetia, Dagestan, Kabardino-Balkaria, etc.), Far Eastern coastal regions.

The main reason for the established "choreography" of the virus spread is the excellent transport characteristics in these territories. Unconditional leaders in the speed and rate of disease, the city of Moscow and the Moscow Oblast possess perhaps the most developed logistical infrastructure. The city of Moscow became the main gateway through which compatriots returned daily from around the world, including during the short "holidays" timed to coincide with the March 8 holiday. Meanwhile, it was Moscow airports that were the first to massively control the body temperature of arriving passengers, that is, to detect cases of infection.

The northern territories of the country, primarily Khanty-Mansi and Yamalo-Nenets Autonomous Okrugs also received an increase in reported cases due to the active arrival of the population, but primarily because of the shift workers. We also believe that these rich regions with effective management teams had the opportunity to test their small population more en masse. Murmansk Oblast, where the number of infected people exceeded 100 per 100 thousand people, as in the case of oil and gas regions, suffered from active labour migration, as major infrastructure projects are being implemented, new ports are being built in this region. The most affected cities are Apatity, Teriberka, Monchegorsk, Kirovsk. The factor of the border location, proximity of Finland and Sweden, also probably became an additional factor of the virus spread.

It must be understood that high recorded values in central and a number of northern regions (especially at early stages) are primarily due to increased entry controls and generally where mass testing of the population is provided. 


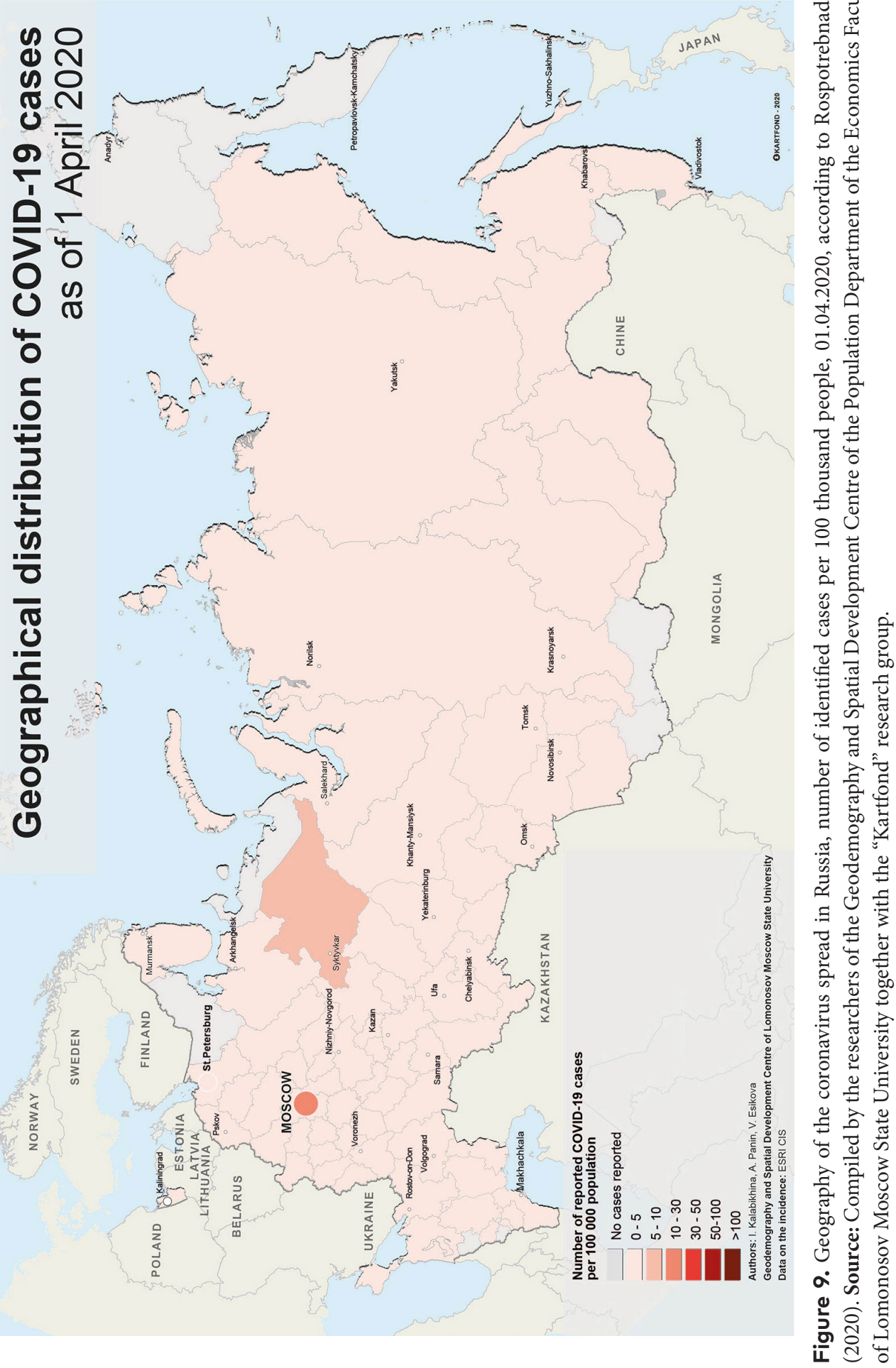



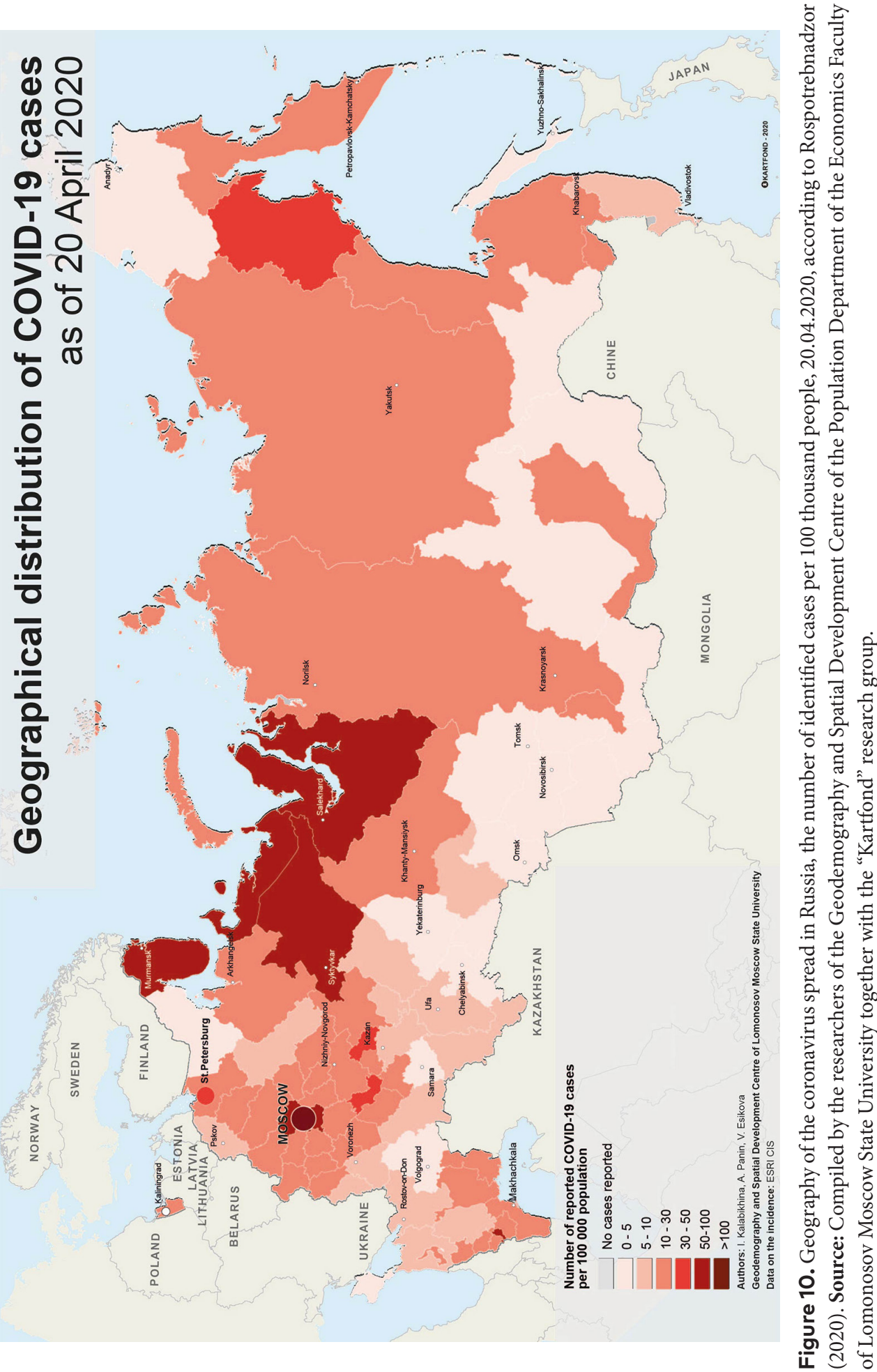

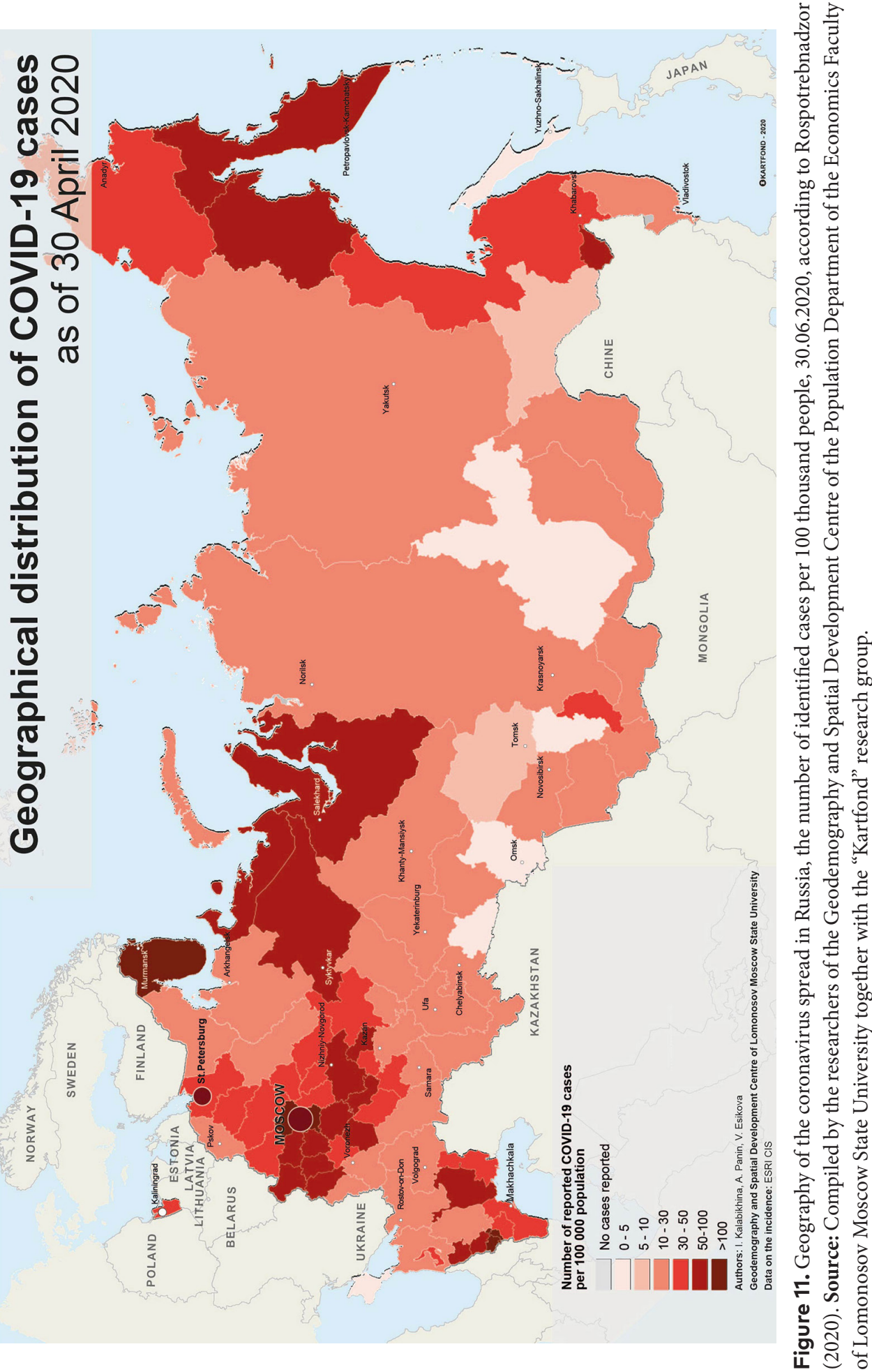
A separate group of leaders is formed by the republics of the North Caucasus, where an increase in a number of infected became noticeable only after April 20. The "specialty" of the North Caucasus, which affected the virus spread, is manifested in the nature of institutional, socio-demographic and political behaviour of the population of the region during last 30 years. Mass religious practices, social practices of close contact and communication, high average household size, active labour contacts with Moscow and the northern regions, lag in socio-economic development from the middle Russian regions, ethnic conflicts and high level of readiness for protests are all characteristics of most regions of the North Caucasian Federal District. People in these regions fear a default of their economies. These regions had the lowest Yandex self-isolation index (less than 2) (Yandex 2020) and low approval of restrictive measures proposed by the authorities (see, for example, protests in Vladikavkaz (Meduza 2020)).

In a certain sense, the North Caucasus owes its presence on the map of registered morbidity as a "leader" to protests in North Ossetia (where the number of tested population increased by 4 times), rigid restrictive measures implemented by the authorities in Chechnya, Ingushetia, Dagestan and Stavropol (primarily in the city of Pyatigorsk), which were introduced together with increased testing of the population.

Transport and logistics functions here are more powerful than in the northern regions. For example, Mineralnye Vody Airport alone receives over 2.5 million passengers each year. Almost every region of the North Caucasus has its own airport, railway branches, federal highway routes. But in these regions, in our opinion, this factor is not basic in explaining their "leadership" in the spread of reported morbidity.

In addition to the described areas, new regions are actively appearing on the map. The coronavirus is "moving" from the centres to the periphery, staining a growing number of Russian regions and municipalities on the map in dark red colour.

By 10 May 2020, the situation worsened, but the centers of the pandemic remained the same - Moscow and neighbouring regions, the northern oil and gas regions and port regions, the North Caucasus regions; the outbreak remains in the Far East (Fig. 12).

At the regional level in Russia, there is a negative correlation between the number of accumulated registered cases of the disease (and mortality) per 100 thousand people from COVID-19 (as of 7 May 2020) and mortality rates for people older than working age (per 100 thousand people, per 2018): -0.35 and -0.46 , respectively.

We obtained very interesting results at the municipal level of analysis (data from Rospotrebnadzor). The spread of the virus from the capital to the periphery is already clearly visible on April 1, when the municipalities of the Central Federal District that are closest to Moscow were affected (Fig. 13). On April 20, 30 and May 10 the situation worsens (Figs 1416). Oblasts' centers are also a source of the spread of the disease, which is especially clearly seen with a point view of the spatial distribution of the virus (Figs 17-18).

How quickly and in which direction did the coronavirus spread from Moscow? Using the centrographical method, we determined that the most active direction of the spread of the disease is the southeast one. The spread of the virus (as the ratio of the number of new cases of the disease per 100 thousand population during the period to the duration of the period) varies greatly in different municipalities (Fig. 19). On the inset map inside Figure 19, it is clearly seen that the direction of displacement of the center of gravity is the southeast direction. The virus propagation speed (as the distance covered by the virus in $\mathrm{km}$ during the period under review) is $40 \mathrm{~km}$ per month (from April 10 to May 10). 

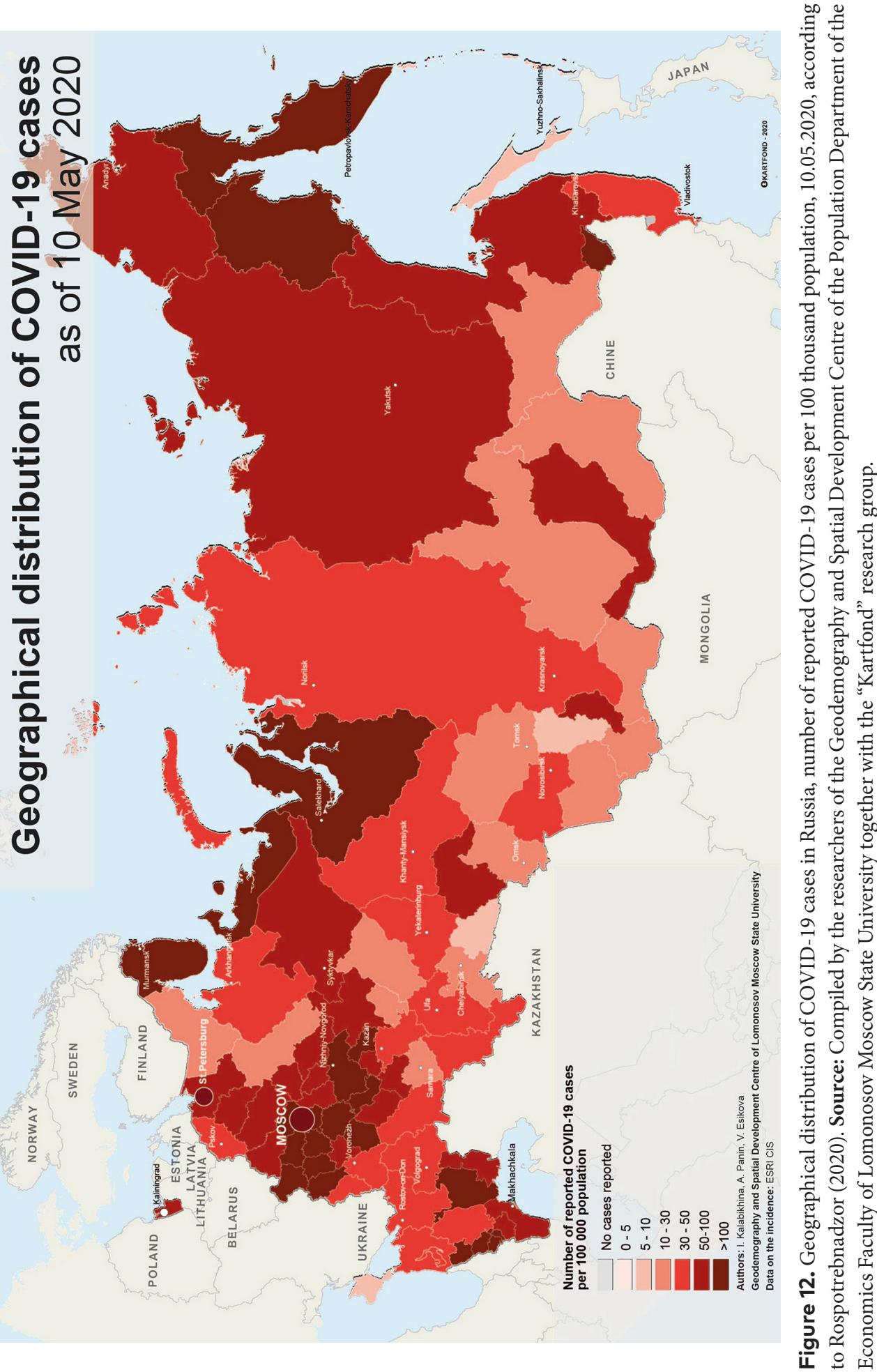


\section{Geographical distribution of COVID-19 cases in the Central Federal District Russia} as of 1 April 2020

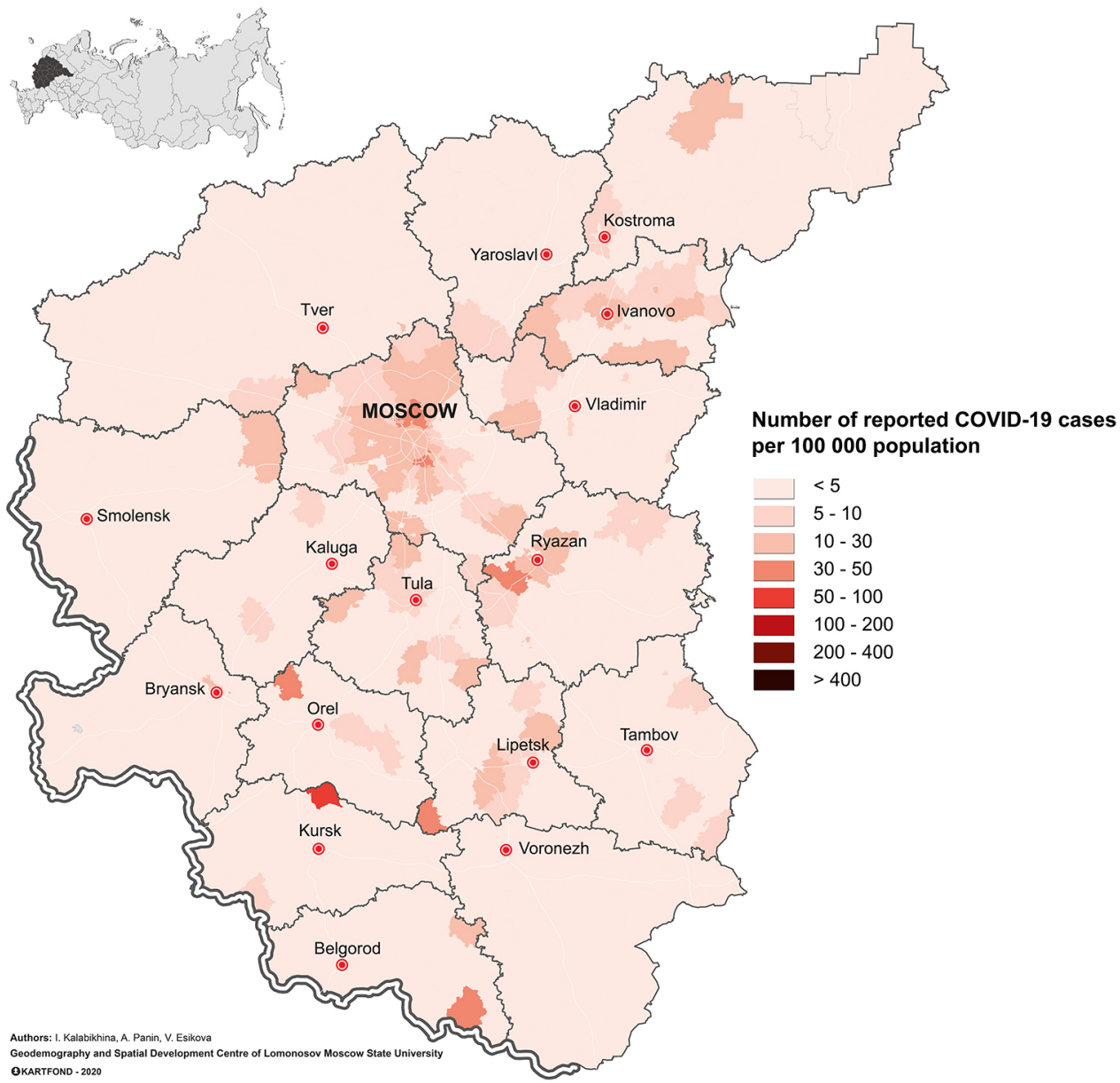

Figure 13. Geographical distribution of COVID-19 cases in the municipalities of the Central Federal District of Russia, number of reported COVID-19 cases per 100 thousand population, 01.04.2020, according to Rospotrebnadzor (2020). Source: Compiled by the researchers of the Geodemography and Spatial Development Centre of the Population Department of the Economics Faculty of Lomonosov Moscow State University together with the "Kartfond" research group. 


\section{Geographical distribution of COVID-19 cases in the Central Federal District Russia} as of 20 April 2020

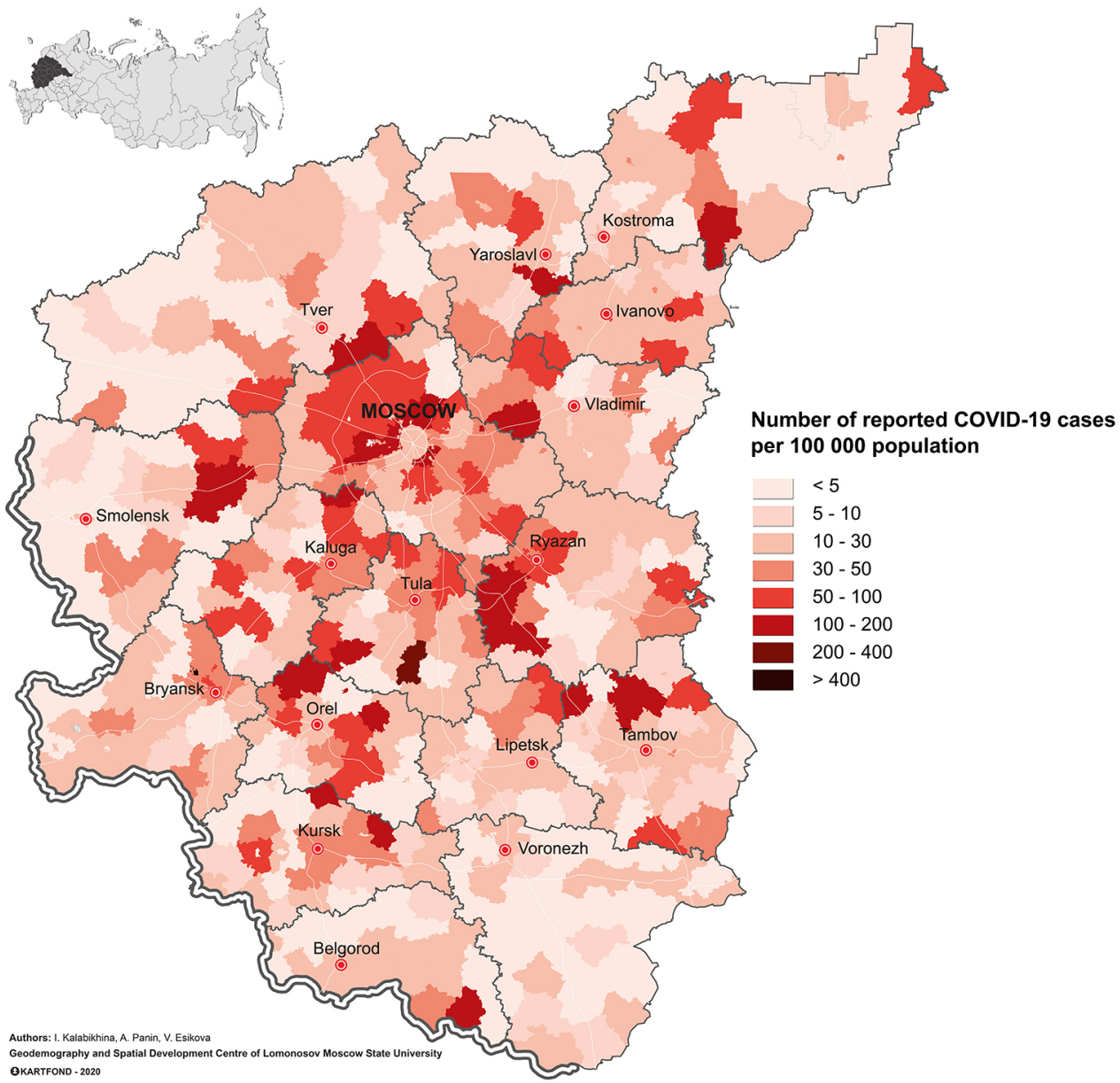

Figure 14. Geographical distribution of COVID-19 cases in the municipalities of the Central Federal District of Russia, number of reported COVID-19 cases per 100 thousand population, 20.04.2020, according to Rospotrebnadzor (2020). Source: Compiled by the researchers of the Geodemography and Spatial Development Centre of the Population Department of the Economics Faculty of Lomonosov Moscow State University together with the "Kartfond" research group. 


\section{Geographical distribution of COVID-19 cases in the Central Federal District Russia} as of 30 April 2020

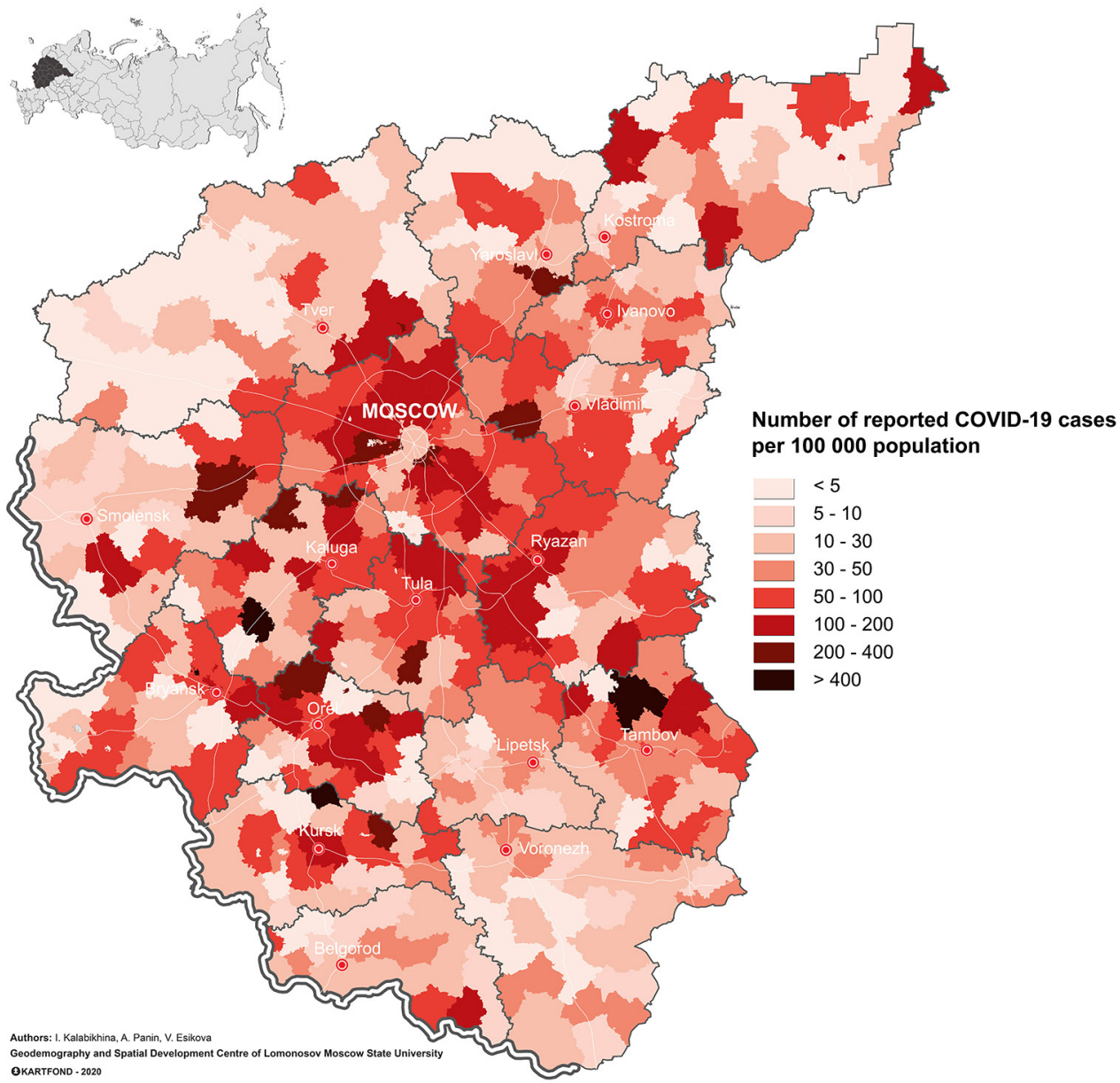

Figure 15. Geographical distribution of COVID-19 cases in the municipalities of the Central Federal District of Russia, number of reported COVID-19 cases per 100 thousand population, 30.04.2020, according to Rospotrebnadzor (2020). Source: Compiled by the researchers of the Geodemography and Spatial Development Centre of the Population Department of the Economics Faculty of Lomonosov Moscow State University together with the "Kartfond" research group. 


\section{Geographical distribution of COVID-19 cases in the Central Federal District Russia} as of 10 May 2020

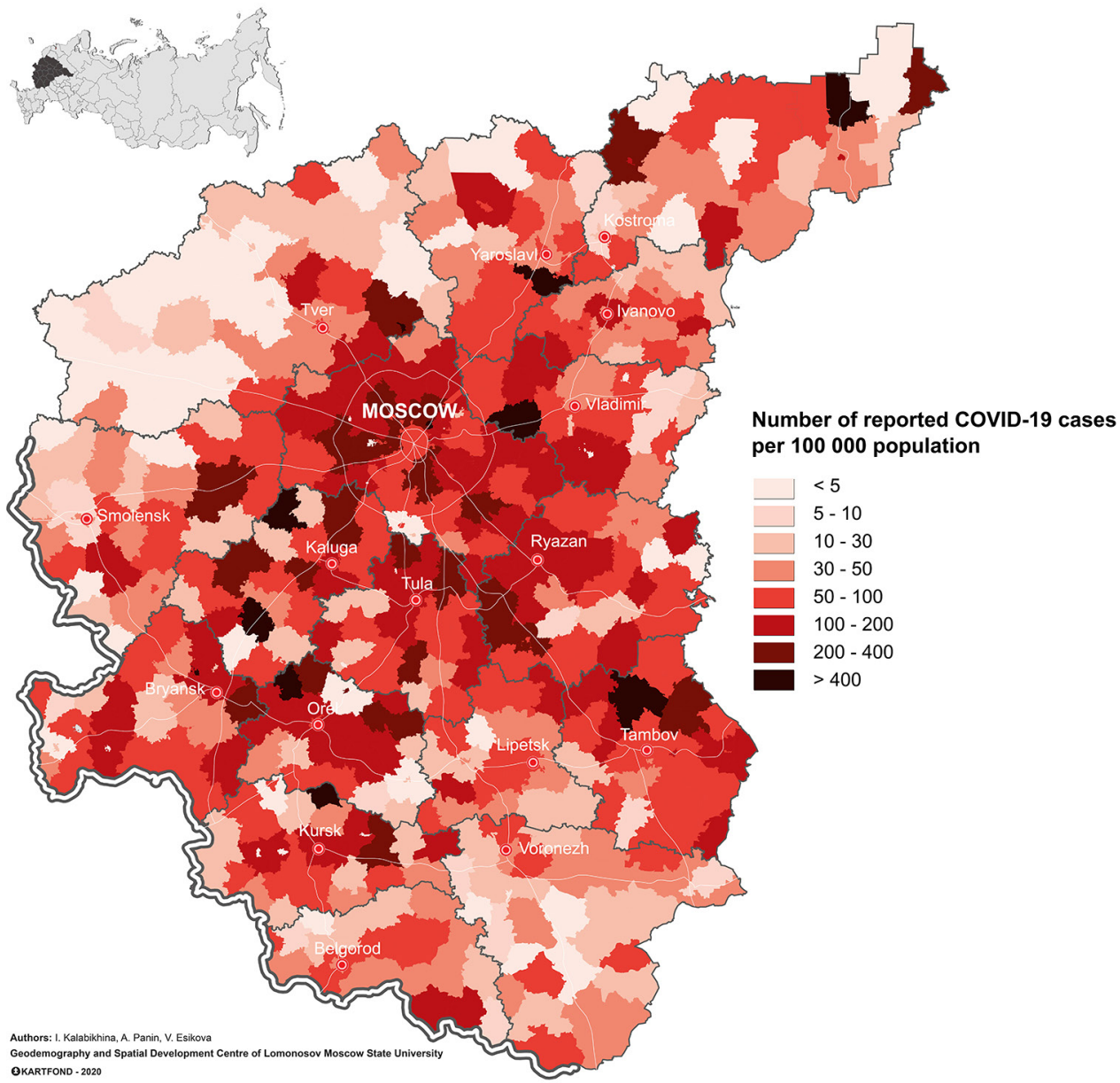

Figure 16. Geographical distribution of COVID-19 cases in the municipalities of the Central Federal District of Russia, number of reported COVID-19 cases per 100 thousand population, 10.05.2020, according to Rospotrebnadzor (2020). Source: Compiled by the researchers of the Geodemography and Spatial Development Centre of the Population Department of the Economics Faculty of Lomonosov Moscow State University together with the "Kartfond" research group. 


\section{Number of infected with coronavirus in the Central Federal District Russia 10 April}

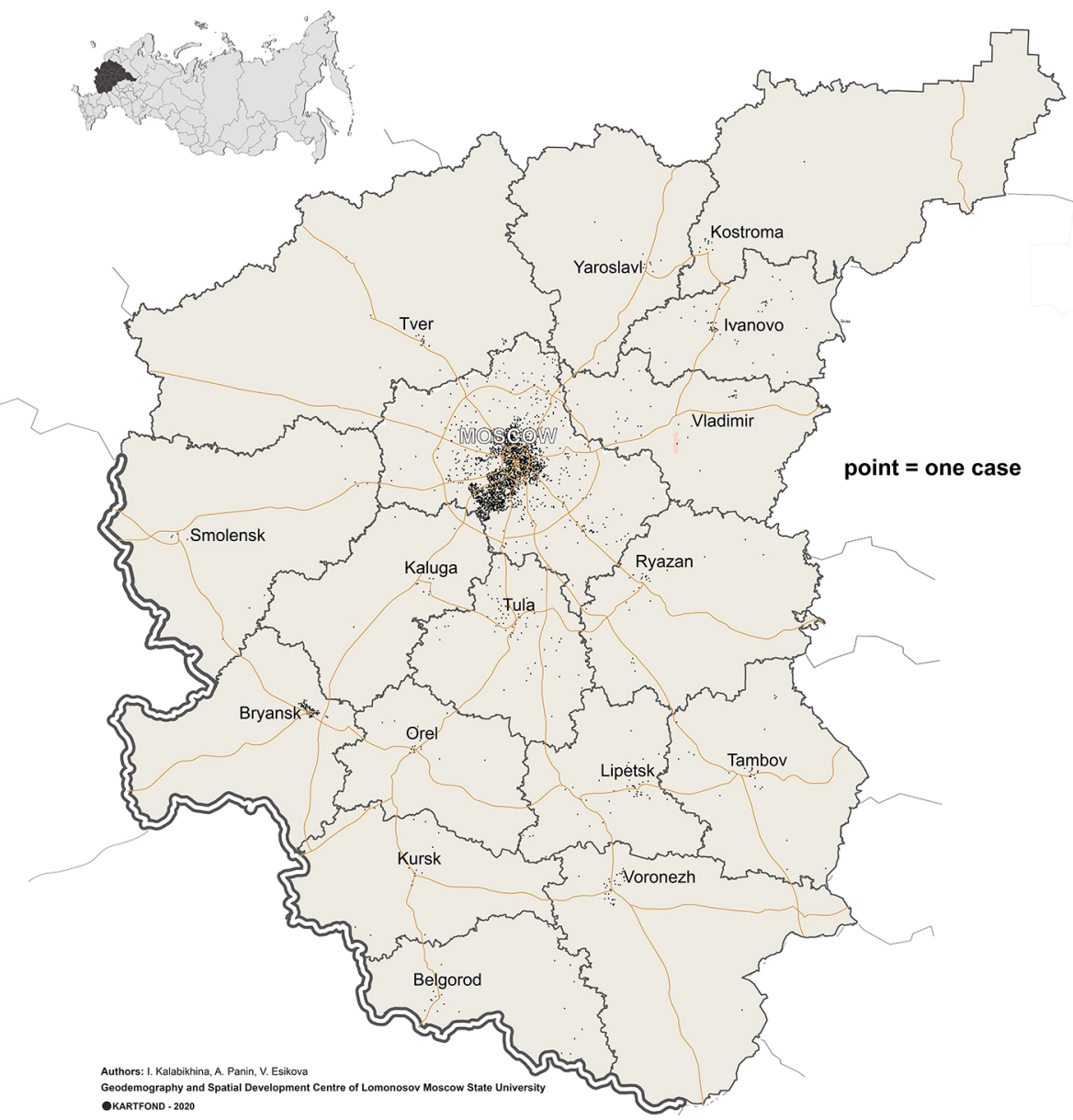

Figure 17. Geographical distribution of COVID-19 cases in the municipalities of the Central Federal District of Russia, number of reported COVID-19 cases, 10.04.2020, according to Rospotrebnadzor (2020). Source: Compiled by the researchers of the Geodemography and Spatial Development Centre of the Population Department of the Economics Faculty of Lomonosov Moscow State University together with the "Kartfond" research group. 


\section{Number of infected with coronavirus in the Central Federal District Russia 10 May}



Figure 18. Geographical distribution of COVID-19 cases in the municipalities of the Central Federal District of Russia, number of reported COVID-19 cases, 10.05.2020, according to Rospotrebnadzor (2020). Source: Compiled by the researchers of the Geodemography and Spatial Development Centre of the Population Department of the Economics Faculty of Lomonosov Moscow State University together with the "Kartfond" research group. 


\section{Speed of the spread of COVID-19 cases per 100000 population in the Central Federal District Russia}

\section{April - 10 May}

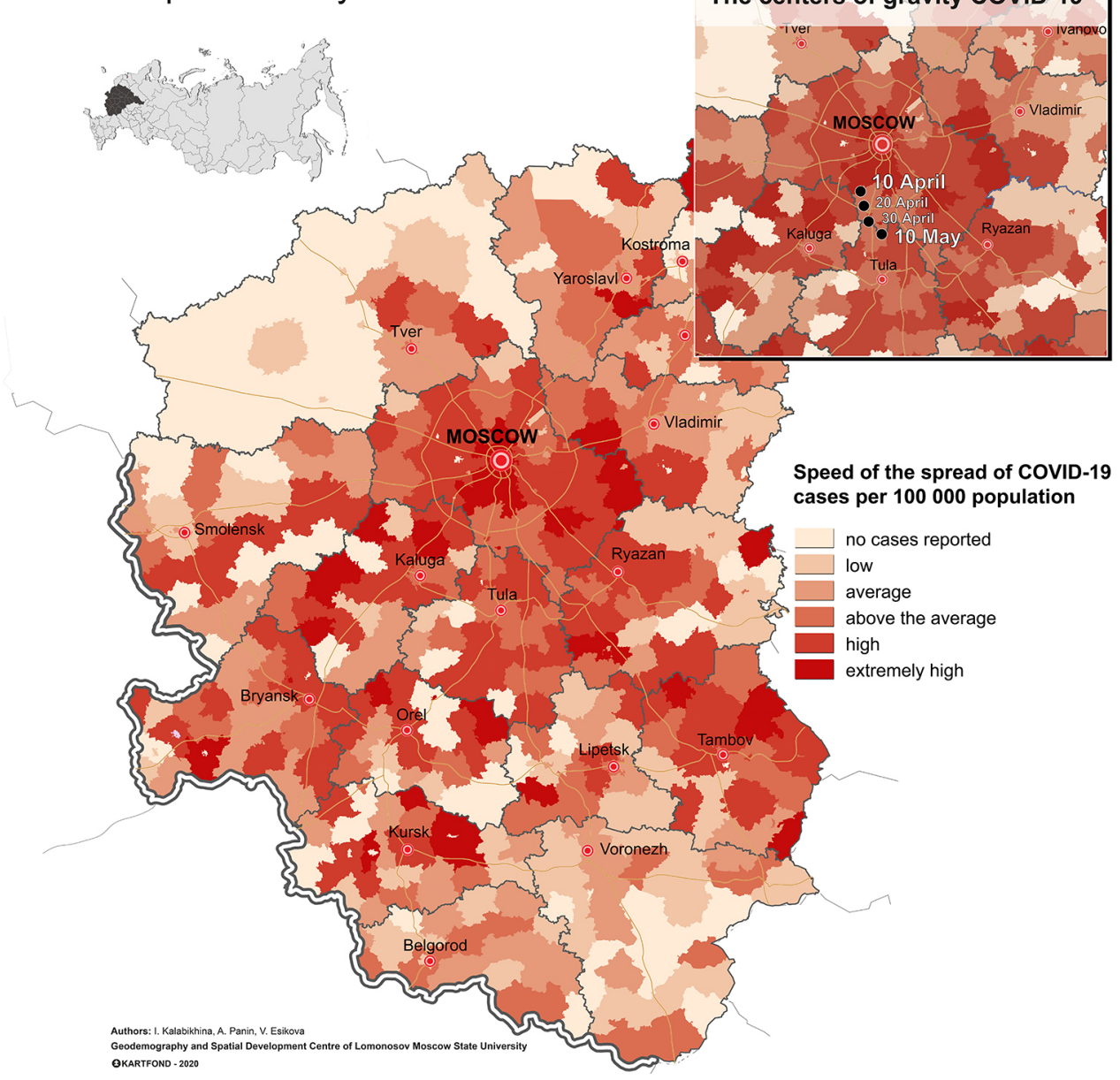

Figure 19. Speed of the spread of COVID-19 cases per 100 thousand population in the municipalities of the Central Federal District of Russia, 10.04.2020 - 10.05.2020, according to Rospotrebnadzor (2020). Source: Compiled by the researchers of the Geodemography and Spatial Development Centre of the Population Department of the Economics Faculty of Lomonosov Moscow State University together with the "Kartfond" research group. Note: No cases reported: $-0.500000-0.000000$ (cases per 100000 population per month); low: $0.000001-0.150000$; average: $0.150001-0.300000$; above the average: $0.300001-0.600000$; high: $0.600001-1.200000$; extremely high: $1.200001-2.900000$. 
At the municipal level in the Central Federal District, there is a weak negative correlation between the number of registered cases of the disease per 100 thousand people (as of May 7) and the share of the population over working age (-0.25) (indicators of natural and migration movement in the municipalities of the Central Federal District in previous years are not related to spread of the disease). To calculate the correlation coefficients, data from Rospotrebnadzor and a database of municipalities of the Central Federal District were used (Kalabikhina et al. 2019).

Returning to the region most affected by the pandemic (by the number of cases) at this point, the city of Moscow - it should be noted that the capital, like most major cities, turned out to be the gateway (certainly not the only one in the country) through which the virus entered and spread. The high risk of contacts in the territory of a large city (metro, other public transport, large shops, offices) increases the risk of rapid spread of the disease.

Other microgeographic and urban factors - density and type of buildings, number of storeys, urban environments and even apartment floor plans - may have a negative impact on the spread of the pandemic (Moscow Center of urban studies... 2020).

But equally important, in our opinion, are socioeconomic factors (standard of living, education, etc.), the behavioural factor (willingness of people to protect their health, consciously observe self-isolation) and factor of the effectiveness of restrictive measures applied in the territory.

At a city level, we do not have published official statistics of the spread of registered cases in Moscow areas. According to unpublished official data, the inner-city dynamics of the spread of morbidity in Moscow looked as follows. At the very beginning COVID-19 was a disease of areas with high reputational status - the center of the capital, western and southwestern areas. These territories have the highest indices of living standards, capital functions are concentrated here, expensive real estate is located here, a significant part of the well-off and educated population of the capital live here (Vendina et al. 2019) Representatives of these areas, returning from overseas business and tourist trips in February and March, were the first carriers of the virus. But the situation changed rather quickly - there are fewer new cases, and less territorial density of such cases. Later, the spread of the virus increased in the peripheral territories (southeast, north of the capital).

On the outskirts of Moscow and in the near outskirts of Moscow Ring Road, especially the eastern region, there was an active increase in cases and a high density of diseased. For example, in the quarter between Vernadsky, Lomonosovsky, Leninsky and Universitetsky avenues there are only 6 cases, 4 of which were recorded from April 1 to April 10, and two new ones (from April 10 to April 20), and in Dzerzhinsky in the large Lesnaya Street - Tomilinskaya Street - Dzerzhinskay Street - Lenina Street quarter with similar height and density of construction there are 41 cases (6 cases recorded from April 1 to April 15), including 35 new ones (as of April 20) (according to unpublished data of the government of Moscow). When final and official data on the spread of the pandemic in the areas of Moscow appear, it is necessary to correlate the dynamics of morbidity with socioeconomic and behavioural characteristics of the population of the city areas such as an opportunity to move to country houses, the average size of households and availability of secondary real estate, level of education, level of self-preservation behaviour, income of households and the opportunity to work remotely or take a vacation.

The effectiveness of the restrictive measures applied in the territory can be analyzed after the end of the epidemic. Below we show territorial differences in the degree of rigidity of restrictive measures. 


\section{Restrictive measures against the coronavirus spread in Russian regions}

According to the Decree of the President of the Russian Federation of 02.04.2020 N 239, the highest officials of Russian regions were instructed to develop and implement a set of restrictive and other measures aimed at ensuring the health and epidemiological well-being of the population. Pursuant to this decree, the heads of regions have already issued over 1000 normative legal acts within a month. At this stage, for spatial analysis of the degree of rigidity of restrictive measures (see methodology in introduction), we have constructed a map of spatial differentiation of restrictive measures against the coronavirus spread the in Russian regions (Fig. 20).

The toughest measures were applied in the city of Moscow, including digital QR codes for the movement of citizens. Following Moscow, a number of regions in the belt of influence of the capital, fearing the "Moscow coronavirus" - Yaroslavl, Ivanovo, Lipetsk and other Oblasts - formed their limitations in the form of tight control of visitors from Moscow.

Many regions have tried to implement tight controls on roads (such as Nizhny Novgorod Oblast). And the Chechen Republic and Crimea at the beginning completely closed entry, but then scaled these limitations down somewhat.

Closure of playgrounds, restaurants, shops (except for grocery stores) and most enterprises were observed in almost all regions (except Sakhalin). Some relief was introduced by regions that were trying to strike a balance between the epidemiological situation and the local economy.

Final conclusions on the nature of the spatial spread of COVID-19 is premature. In future, we will assess an increase in total population mortality in the regions during the pandemic wave, analyze the effectiveness of measures taken and the impact of other factors on mortality, and see spatial imbalances of countries, regions and municipalities on the map. The use of the theory of diffusion of innovations (Rogers 2010) is promising in explaining the spatial spread of the pandemic. 


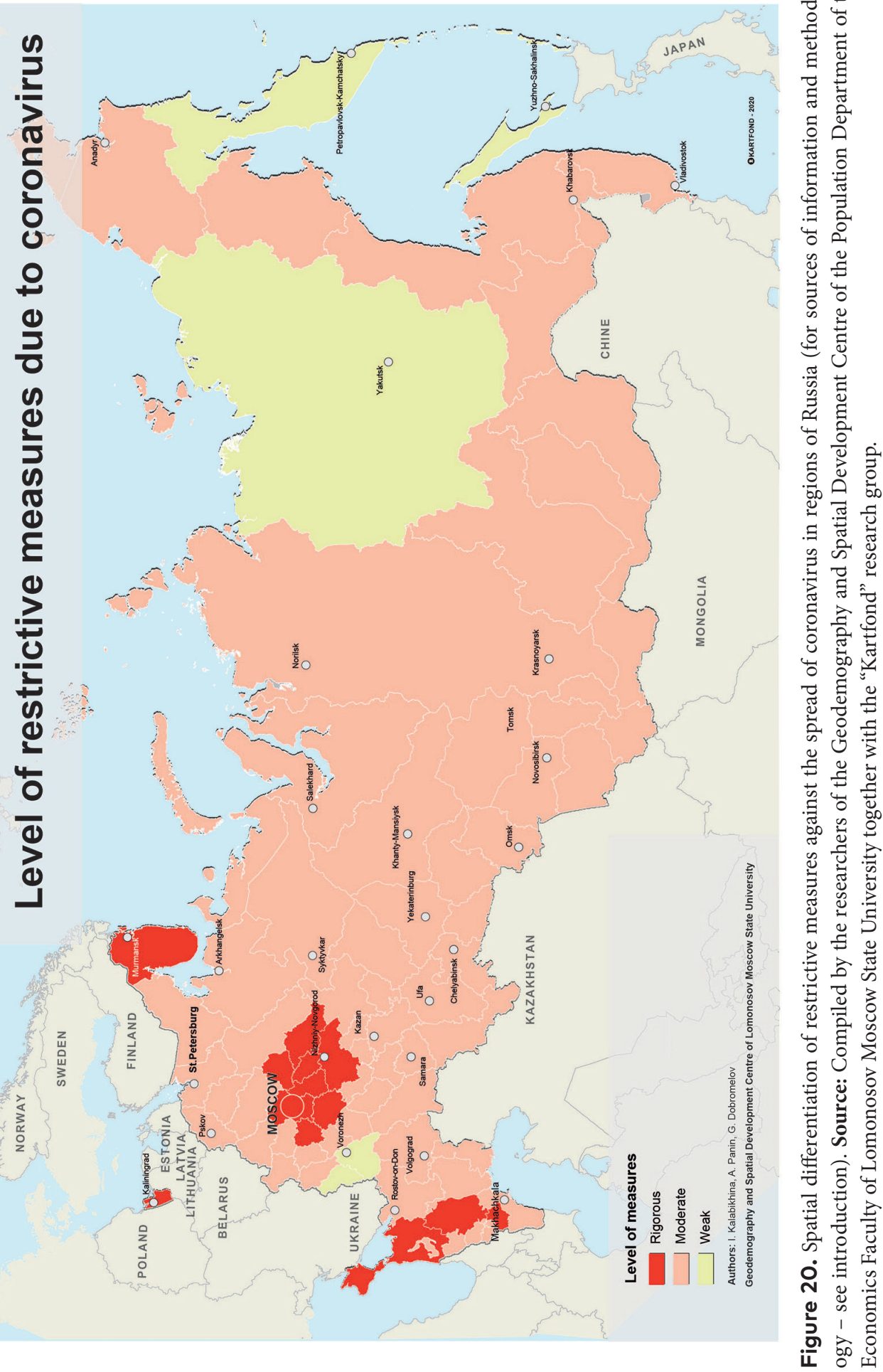




\section{Reference list}

Cembalest M (2020) Eye on the market. https://am.jpmorgan.com/content/dam/jpm-am-aem/global/ en/insights/eye-on-the-market/COVIDv2.pdf [Accessed on 20.05.2020]

Decree of the President of the Russian Federation of 02.04.2020 N 239 "On measures to ensure the sanitary and epidemiological well-being of the population in the Russian Federation in relation to the spread of a new coronavirus infection (COVID-19)" http://www.consultant.ru/document/ cons_doc_LAW_349217/ [Accessed on 20.05.2020] (in Russian)

Garant (www.garant.ru) (in Russian)

Johns Hopkins University: COVID-19 Data Repository by the Center for Systems Science and Engineering (CSSE) at Johns Hopkins University. https://github.com/CSSEGISandData/COVID-19 [Accessed on 20.05.2020]

Kalabikhina IE, Mokrensky DN, Panin AN (2019) Demographic, economic, geospatial data for municipalities of the Central Federal District in Russia (excluding the city of Moscow and the Moscow oblast) in 2010-2016. Population and Economics 3(4): 121-134. https://doi.org/10.3897/popecon.3.e39152

Meduza (2020) In Vladikavkaz hundreds of people staged a rally against the self-isolation regime. https://meduza.io/feature/2020/04/20/vo-vladikavkaze-sotni-lyudey-ustroili-miting-protiv-rezhima-samoizolyatsii-glavnoe [Accessed on 20.05.2020] (in Russian)

Mendeleev D (1907) Towards cognition of Russia. Suvorin Publishing House, Saint Petersburg, 158 pp. http://alcdata.narod.ru/Mendeleev_K_poznaniyu_Rossii_1907/Mendeleev_K_poznaniyu_Rossii_1907.pdf [Accessed on 20.05.2020] (in Russian)

Moscow Center of urban studies, TASS, Habidatum: Monitoring of the state of Moscow areas during the period of prevention and control of coronavirus infection. http://goroda.moscowurbancenter. ru/ [Accessed on 20.05.2020] (in Russian)

Panin AN, Tikunov VS (2016) Centrographical method for the analysis of the indigenous minorities' settlement (case study of the minorities of the North, Siberia and the Far East). Vestnik Moskovskogo universiteta. Seriya 5: Geografiya. [Bulletin of the Moscow State University. Issue 5: Geography] (6): 104-106. https://www.elibrary.ru/item.asp?id=28821412 [Accessed on 20.05.2020] (in Russian)

Polian PM, Treivish AI (1990) Centrographical method for the analysis of the territorial structures: problems of development and application. Izvestiya Rossiiskoi Akademii Nauk. Seriya Geograficheskaya [News of the Russian Academy of Sciences. Geographic series] (2): 92-105. (in Russian)

Rogers E (2010) Diffusion of Innovations. Free Press, 518 pp.

Rospotrebnadzor: Relevant epidemic situation in Russia and the world. https://www.rospotrebnadzor. ru/region/korono_virus/epid.php [Accessed on 20.05.2020] (in Russian)

The Oxford COVID-19 Government Response Tracker (OxCGRT): Coronavirus Government Response Tracker. https://www.bsg.ox.ac.uk/research/research-projects/coronavirus-government-response-tracker [Accessed on 20.05.2020] (in Russian)

Vendina O, Panin A, Tikunov V (2019) The Moscow Social Space: Features and Structure. Regional Research of Russia 9: 383-395. https://doi.org/10.1134/S2079970519040117

WHO: Coronavirus Disease (COVID-19) Dashboard https://covid19.who.int/ [Accessed on 20.05.2020]

Yandex: Index of self-isolation. https://yandex.ru/maps/covid19/isolation?ll=41.775580\%2C54.89402 $7 \& z=3$ [Accessed on 20.05.2020] (in Russian)

Yandex.Maps: The city of Moscow and the Moscow oblast https://xn----btbherjcsnjlj1p.xn--p1acf/online/moskva-i-oblast. [Accessed on 20.05.2020] (in Russian) 
Zyryanov AI (2020) Geography of the spread of the coronavirus. Proza.ru. https://proza. ru/2020/04/11/716?fbclid=IwAR06R-RiT-oAecWdJLuB_1IYbQ2tJ9B-9z6IGUrXaGIQzHFEPmDVu1dSFY0 [Accessed on 20.05.2020] (in Russian)

\section{Information about the authors:}

- Irina Evgenyevna Kalabikhina - Doctor of Sciences (Economics), Professor, Head of the Population Department of the Faculty of Economics of Lomonosov Moscow State University. E-mail: ikalabikhina@yandex.ru

- Alexander Nikolaevich Panin - Candidate of Geographic Sciences, Director of the Geodemography and Spatial Development Center of the Population Department of the Faculty of Economics of Lomonosov Moscow State University, Senior Research Fellow at Complex Mapping Research Laboratory of Lomonosov Moscow State University, Head of the "Kartfond" research group. E-mail: alex_panin@mail.ru 